\title{
A New Crusade: Johannes Tinctor's Sect of Witches
}

\author{
Matthew J. Punyi
}

The witch-hunt of the Burgundian town of Arras in 1459-1460 was the first largescale, state-sponsored witch-hunt of Western Europe. However, immediately following this witch-hunt we still find evidence of a reluctance to accept the realities of witchcraft among the populace, made plain in the official appeal record of the accused Seigneur Colard de Beaufort at the parlement de Paris. Scepticism of this kind stirred the Dominican cleric Johannes Tinctor out of retirement to write a vicious demonological treatise to convince the courts of Burgundy and France of the existence and dangers of a sect called vaudois, a term that had come to refer to witches. This essay closely examines Tinctor's heavy use of crusading imagery in his Invectives contre la secte de vauderie to justify and rationalize his arguments for duke Philip the Good of Burgundy and his court, a court renowned for consistent but empty promises of crusade and an elaborate culture bloated with an idealized infatuation with chivalric virtue and romance. In the autumn of the middle ages, when the traditional eastern crusade against "Saracens" had become frustratingly difficult to organize, what could be more appealing to a court so starved for crusade than a cry for war against an even greater enemy hiding amongst the populace, threatening Christendom from within?

The witch-hunt of the Burgundian town of Arras in 1459-1460 was the first large-scale, statesponsored witch-hunt of Western Europe. Although the trial records themselves were burned near the century's end, the record of the accused Seigneur Colard de Beaufort's appeal to the parlement de Paris reveals most of what we know about the trials. The inquisitors at Arras began their hunt at the bottom of the social hierarchy. They first put to the question a prostitute named Denisette and quickly moved their way up the ranks, eventually making the mistake of accusing, imprisoning and harassing members of the lower nobility. Unfortunately for the inquisitors and the Bishop of Arras, Colard de Beaufort was not a vassal to the dukes of Burgundy, but to king Louis XI of France, which gave him the right to escape the jurisdiction of the Burgundian courts and appeal directly to the advanced legal entity of the parlement de Paris, where the case was accepted and heard over the span of nearly a decade. For our case it is interesting to find evidence within the appeal records of a reticence to accept the realities and dangers of the kind of malefic witchcraft that the people of Arras had been accused of. We find this reticence, notably, among the ranks of men like Jean de Popaincourt, who represented Beaufort on behalf of the king. ${ }^{1}$ The tone in which these men spoke reveals that the "elaborated theory of witchcraft" had not yet been normalized among the populace. However, it was this sort of scepticism and unbelief that stirred the Dominican cleric Johannes Tinctor out of retirement to mobilize his

\footnotetext{
${ }^{1}$ Popaincourt states, "And it is not at all possible that one might fly through the air using nothing but a stick. According to rights, those who believe this are even greater heretics than those who claim to have done it," "Appeal to the Parlement of Paris," Unpublished; trans. Andrew Gow, Robert Desjardins and François Pageau, 62.
} 
theological prowess in the fabrication of an elaborate demonological witch-hunting treatise. Its goal was to provide the elite of Burgundy with a learned scholastic rationalization for the existence of and justification for the extermination of a sect called vaudois, a term that had come to refer to witches.

Tinctor's Invectives contre la secte de vauderie was, indeed, one of the earlier demonological witch-hunting handbooks, surfacing a few decades before Heinrich Institoris and Jacob Sprenger's popular Malleus Maleficarum. The original treatise was written in Latin around 1460, but the urgency of the topic seemed to have warranted a French translation several years later to be of use to a broader demographic. ${ }^{2}$ Tinctor's primary readers would have been the French and Burgundian nobility at court. A copy was even made for the ducal library of Philip the Good himself, who reigned in the duchy of Burgundy from 1419-1467. The treatise described the vaudois as a purely evil inversion of all Christian morals and values. Tinctor explained that this sect was a much worse enemy to God than any heretic, idolater, pagan or Muslim. ${ }^{3}$ Their evil was unique in that they consciously engaged in evil for evil's sake. They gave the reverence and sacrifice due to God instead to the Devil, even after having been baptised into Christianity and having lived for years among Catholics. This blatantly evil behaviour and activity made the vaudois apostates of the highest degree. ${ }^{4}$ However, when studying Tinctor's Invectives it also becomes very clear that he was aware of his audience, not only in his explicit exhortations to individual castes of the elite, but also in the rhetorical and persuasive strategies in which he unpacked his ideas throughout. Since we know that the idea of malefic witchcraft was "never before heard-of", as explicitly stated by Tinctor himself a number of times in the treatise, and as demonstrated in reality by the scepticism found in the Arras appeal, it is understandable that Tinctor would be forced to present his arguments in terms that would be comprehensive, convincing and appealing to the Burgundian elite and their unique culture. ${ }^{5}$ Upon study of the treatise, it seems obvious that Tinctor chose to use the idea of the crusade to achieve these ends. Tinctor's treatise can be read as an explicit, and implicit, call to the Burgundian and French Militia Christi to take up arms against this new threat to Christendom. Tinctor's treatise provides convincing justification for a holy war against witches, and he thoroughly explains why it would be the duty of the ruling class and elite to wage this war to protect the "most Christian kingdom" of the French as defenders of the faith. I have decided to look at this treatise through this lens of crusading imagery, to discover some of Tinctor's conscious strategies for captivating the chivalric emotion of his Burgundian readers. To do this, it would first be important to provide context for the treatise by introducing and discussing the significance of chivalric crusading culture at Philip the Good's Burgundian court in the fifteenth century.

In James Hankins' study of fifteenth century humanism in relation to the crusade he refers to the duchy of Burgundy, despite its constant and generous promises to crusade, as invertebrate. ${ }^{6}$ By

\footnotetext{
${ }^{2}$ I will be referring to Johannes Tinctor, Invectives contre la secte de vauderie, Unpublished; trans. Andrew Gow, Robert Desjardins, and François Pageau.

${ }^{3}$ Tinctor, Invectives, Fol. $7 \mathrm{v}$.

${ }^{4}$ Tinctor, Invectives, Fol. 18r-19r.

${ }^{5}$ Tinctor, Invectives, Fol. $17 \mathrm{r}$ "it is certain that this crime is entirely new nor was its like ever heard of...," Fol. "...newly introduced and never before heard-of evil," Fol. 23v.

${ }^{6}$ James Hankins, "Renaissance Crusaders: Humanist Crusade in the Age of Mehmet II," Dumbarton Oaks Papers 49 (1995): 113, accessed December 8, 2013 http://www.jstor.org/stable/1291712.
} 
describing Burgundy thus, Hankins harshly exposes the duchy's embarrassing reputation as a limp crusading state in its later years. Hankins' statement proves partially true, but the invertebrate nature of this late medieval "crusading" state was far from what the Burgundian dukes had hoped for. The duchy of Burgundy was enamoured and enchanted with the idea of crusading, for a crusade was the ultimate public demonstration of piety and chivalry.

Performance of a crusade automatically translated into glory, honour and hereditary reputation. It was an ideal mixture of the Christian pilgrimage and a war campaign. But the idea of the crusade that had been romanticized and idealized by the fifteenth century was becoming less feasible in the reality of a Europe recovering from Church schism, plague, the 100 Years' War, general inner strife and political changes. The duchy of Burgundy adopted a romantic vision of the chivalric crusade and internalized it, modelling its own court life on exaggerated knightly piety and mock war culture, which was highly influenced by stories of heroes of the past and chansons de geste. ${ }^{7}$ This largely manifested itself at court in the form of jousts, elaborate festivals, public displays of ritual piety, processions, knightly pageantry, and the production of arts. The production of pseudo-historical romantic novels based on the lives of crusading favourites like Godfrey de Bouillon, or classical and mythological figures, and heroic medieval kings also massively grew in popularity. Copies of these pieces of literature, like the Cronicques et Conquestes de Charlemaigne and L'Histoire de Charles Martel, were commissioned by Philip the Good, and inspired him and his knights at court with the spirit of chivalry and stoked their dreams of crusade. $^{8}$ Philip's foundation of the famous Order of the Golden Fleece, in itself, was intended to be a chivalric crusading order modelled on the popular Greek mythology of Jason and the Argonauts.

Chivalry in Burgundy relied heavily on these historical and mythological role models. Ancestry was also an essential motivator for Philip the Good, in particular. As duke of the junior branch of the French Valois dynasty, Philip could trace his crusading background to illustrious royalty and French heroes of old, from his own father to Saint Louis and, of course, even to the legendary Charlemagne. Philip's library was laden with crusading chronicles, chansons de geste and fictional retellings of heroic crusaders' deeds, and accounts of these important Christian leaders. ${ }^{9}$ Gerhild Williams says that these histories and texts were adapted to Philip's political schemes and written to legitimize his ambitions. ${ }^{10}$ Whether these famous characters were directly associated with crusade or not, they and their legends, like that of the Golden Fleece, were manipulated and baptised by Philip to suit his chivalrous goals and interests. Charlemagne, in particular, was a very important figure for Burgundy because he symbolized a mythic Golden Age of the united Christian kingdom of the Franks, whether this ideal was reality or not. In fact, since the First Crusade, Charlemagne and his Frankish heirs had been exalted throughout

\footnotetext{
${ }^{7}$ Robert Desjardins, "Writing and Imagining the Crusade in Fifteenth-Century Burgundy: The Case of the Expedition Narrative in Jean de Wavrin's Anciennes Chroniques d'Angleterre" (PhD Diss., University of Alberta, 2010), 68.

${ }^{8}$ Jacques Paviot, "Burgundy and the Crusade," in Crusading in the Fifteenth Century: Message and Impact, ed. Norman Housley, (UK: Palgrave Macmillan Ltd., 2004), 76-77.

${ }^{9}$ David Wrisley, "The Loss of Constantinople and Imagining Crusade at the Fifteenth-Century Court of Burgundy," al-Abhath 55 (2007-08): 88.

${ }^{10}$ Gerhild Williams, "How to Make Friends: Burgundian Politics in Two Early Modern Prose Texts (Hug Schapler and Girart de Roussillon)," The Sixteenth Century Journal 20 (1989): 277, accessed December 8, 2013, http://www.jstor.org/stable/2540663.
} 
crusading history for halting the Islamic invasions into Western Europe. ${ }^{11}$ Regardless, this same romantic and idealistic essence of Christian unity found within the figure of Charlemagne can be paralleled with a very similar notion conjured by Jean Germain, the bishop of Nevers, chancellor of the Golden Fleece and Philip the Good's primary crusading advocate, at the chapter of the Golden Fleece at Mons in 1451. Here, Germain presented to Philip and his knights a Mappemonde, a map accompanied by a list of all lands that were previously known to be Christian. ${ }^{12}$ Both this Mappemonde and the figure of Charlemagne essentially shared the same symbolic and motivational goals for Philip and his knights, that of a united French Christendom. It became the role of the Order of the Golden Fleece not only to restore the Christian kingdom of Charlemagne, but also to expand it. It should not come as a surprise, then, to learn that Johannes Tinctor conjured the figure of Charlemagne in his treatise, seemingly to arouse the crusading emotions of the Burgundian court, to demonstrate the values to be found in the purification of their "most Christian kingdom" through the extermination of its witches. Tinctor also provided the figure of Charlemagne to set the highest example of the ideal Christian knight, as a role model for the princes of Burgundy as they embarked on their mission to eliminate the enemies of Christ for the good of all Christianity. He stated:

And can it be that the most glorious Charlemagne, king of the most chivalrous French, is celebrated above all other princes of the world by such a singular praise and by such a glorious memory, unless for his constant efforts, of great diligence and with constant labour, to enlarge and expand the limits of holy Christendom, for without resting he exalted the reputation of Christianity, and defended it against all enemies with great skill? ${ }^{13}$

In context, the existence of an evil and heretical sect of witches was damaging to the ideal of Charlemagne's unified Christendom. This ideal, so recently reinforced by Germain's presentation of the Mappemonde, was fresh and ever-present at a court obsessed with Charlemagne's adaptable history. The witches' threat to this ideal kingdom reasonably warranted their extinction. It was up to the heirs of Charlemagne in Burgundy to defend this kingdom "against all enemies with great skill," as he surely would have done himself.

In fact, Tinctor also spared time to call upon the names of many individual biblical heroes to serve the same purpose, including David, Joseph, Pinchas, Caleb, Abraham, Elijah, Daniel, and even Jesus. ${ }^{14}$ He did not forget, also, to mention the holy saints, martyrs and doctors as collective groups to whom his readers may aspire in their holy expedition against Christ's enemies. ${ }^{15}$ Tinctor called upon the princes to "remember the glorious past." ${ }^{16}$ He provided an invitation and opportunity for these most deprived knights to imitate their literary and ancestral heroes:

${ }^{11}$ Elizabeth J. Moodey, Illuminated Crusader Histories for Philip the Good of Burgundy (Belgium: Brepols Publishers, 2012), 82.

${ }^{12}$ Paviot, "Burgundy and the Crusade," 72.

${ }^{13}$ Tinctor, Invectives. Fol. $47 \mathrm{r}-47 \mathrm{v}$.

${ }^{14}$ Tinctor, Invectives, $45 \mathrm{r}-46 \mathrm{r}$.

${ }^{15}$ Tinctor, Invectives, $46 \mathrm{r}-47 \mathrm{r}$.

${ }^{16}$ Tinctor, Invectives, $45 \mathrm{r}$. 
May it please you to recall to your mind's eye the lofty exploits and memorable deeds which the most noble princes did long ago out of the ardent devotion they had for the holy law of God. May it please you, for God's sake, to imitate and follow them, now that you have such a fine opportunity to do so. ${ }^{17}$

Philip the Good himself was very intricately bound to the romanticism and idea of the crusade, and his obsession was all-permeating. This obsession was not unwarranted, for Philip's father, John "the Fearless", was the last Burgundian duke to personally lead a crusade. He participated in the crusade of Nicopolis in 1396, and was imprisoned by the Turks under Bayezid I. Despite the massive and brutal loss at Nicopolis and John's humiliating capture, his Christian bravery in the performance of a crusade was exalted, so it would be right to believe that inherent crusading expectations were immediately set for Philip through his father's deeds from very early on. ${ }^{18}$ It is also likely that an element of familial vengeance and the memory of his father's loss at Nicopolis may also have been involved in Philip's obsession with crusade. ${ }^{19}$ Considering the inheritable nature of crusading, conducting a holy war essentially became a legitimizing rite of passage for French rulers. Considering this, the situation of Burgundy in relation to France may have also played a role in this obsession. Burgundy, still technically a vassal of France, had been gaining independence, and perhaps if Philip could have managed to organize a crusade it would have gained him enough prestige to break away from France and even gain him a royal title. ${ }^{20}$ Regardless, for all their imaginary and idealistic role play, and contrary to the traditional conception that the chivalrous and crusading dreams of Burgundy were nothing more than empty mimicry and shadows of the dying chivalric culture of the Middle Ages, Philip the Good and his court were serious about planning a real crusade. It was this solemn desire that became significant enough for Tinctor to exploit it.

Philip the Good had made serious efforts to negotiate a crusade and we find, in addition, that he did not limit himself to crusade against "Saracens". For example, as part of a fairly early attempt, Philip negotiated from 1428 to 1433 with Pope Martin V to embark on a crusade against the Hussite heresy in Bohemia, but this never panned out. ${ }^{21}$ However, to the amazement of European Christendom, in 1453 Constantinople fell under the cannon-fire of the Ottomans, as they laid siege to the city under Sultan Mehmet II. It was the fall of Constantinople that aroused the full and serious crusading intent of Philip and his court. A year later in 1454, at Lille, Philip hosted the Feast of the Pheasant, where he and his knights of the Golden Fleece expressed their intent to crusade. Modelled on the popular chanson de geste by Jacques de Longuyon, Les Voeux de Paon (The Vows of the Peacock), and possibly, as we are reminded by Gail Orgelfinger, also inspired by accounts of the vows taken at Edward I of England's coronation over swans, Philip and his knights took vows over a Pheasant to wage holy war against the enemies of Christ and to restore

\footnotetext{
${ }^{17}$ Tinctor, Invectives, $45 \mathrm{r}$.

${ }^{18}$ Desjardins, "Writing and Imagining the Crusade," 32-33.

${ }^{19}$ Wrisley, "The Loss of Constantinople," 87.

${ }^{20}$ Desjardins, "Writing and Imagining the Crusade," 35.

${ }^{21}$ Ibid., 35.
} 
Constantinople to Christian rule. ${ }^{22}$ Although this particular episode has been subject to much criticism, as the knights have been accused of a lack of sincerity and an overall meaningless extravagance, we are reminded also by Orgelfinger that the vows should not be completely dismissed simply because of their extravagance. ${ }^{23}$ Philip's vow, at least, was a solemn promise to crusade, a promise he genuinely tried to keep.

Now that Philip had made his official "vow of the pheasant" in front of his knights, he had to find a way to fulfill it. Although the papacy, from Martin V to Pius II, worked with Philip to bring a crusade to fruition, he was never able to gain the support necessary from his neighbouring kingdoms. Jacques Paviot points out several episodes in which Philip's crusading attempts failed, and these episodes will be useful to repeat here in order to put Philip's crusading history into perspective. ${ }^{24}$

Pope Nicholas V chose 1 March 1454 as an official date for crusade. Philip immediately sent embassies to the German and Imperial diets, but these diets failed to show their support and Emperor Frederick III refused to attend. This delayed Nicholas' date and he died in 1455, laying these plans to rest. The next plan was proposed by Pope Calixtus III, who decided on 1 March 1456 as the new crusading date. This time, Philip ran into trouble with King Charles VII of France who delayed his plans until, again, the pope died in 1458. Aeneas Piccolomini succeeded in 1458 as Pope Pius II. He proposed new plans for crusade and exhorted Philip to take the reigns again, to lead the armies of Christendom as defender of the faith. Pius went so far as to arrange a crusading alliance between Burgundy and the Republic of Venice in 1463, however King Louis XI forbade Philip from following through. Pius II died in 1464. James Hankins explains that the failure of crusades in the Late Middle Ages was much related to the failure of the papacy to found a monopoly on violence following the Church schism. ${ }^{25}$ This monopoly on violence had passed into the hands of secular lords whose interests were virtually impossible to align. Despite the persistent enthusiasm of Philip and the Popes to organize a crusade, they were nonetheless bound to the interests of neighbouring kingdoms and blocked on all sides.

As demonstrated by the embarrassing trajectory of Philip the Good's many failed efforts, the idea of a traditional crusade was, by this point, becoming less likely for him, especially considering his impending death in 1467. Considering these failures mixed with his ever-burning desire for crusade, Johannes Tinctor's demonological treatise was convincingly written in a way that would reasonably provide Philip and the Burgundian court with a rationalized and alternative "other" against whom the knights of the Golden Fleece could essentially fulfill their chivalric "vows of the Pheasant." Tinctor offered the vaudois in lieu of the traditional enemies of Christ and displayed his treatise in terms of opportunity. In fact, Tinctor's sect of witches really was described in terms that would have made their existence not only understandable but even more appealing to the crusading mind than the "Saracens" dwelling in the east. For Tinctor explained that this sect disguised themselves as Christians; they attended mass and even received the holy

\footnotetext{
${ }^{22}$ Gail Orgelfinger, "The Vows of the Pheasant and Late Chivalric Ritual," in The Study of Chivalry: Resources and Approaches, ed. Howard Chickering, et al. (Michigan: Medieval Institute Publications, 1988), 613-615.

${ }^{23}$ Orgelfinger, "The Vows of the Pheasant," 612.

${ }^{24}$ Paviot, "Burgundy and the Crusade," 74-75.

${ }^{25}$ Hankins, "Renaissance Crusaders," 113.
} 
sacraments. ${ }^{26}$ This fact not only exposed this sect of witches as heretical and deceitful host desecrators, worthy of punishment either way, but it also implied that this sect was hidden amongst them. Although the obvious reaction to this near and hidden malefic evil would be fear and panic, it also meant that there would be no need for crusaders to mobilize supporters, raise funds, cross seas or travel to distant and unknown lands to achieve their goals. They had merely to hunt the witches in their own backyard. Tinctor's offering of witches would eliminate Philip's tireless hours spent "raising funds from his estates, commissioning advisory tracts, and pursuing continental diplomacy." ${ }^{27}$ It would also mean that Philip and his knights would no longer have to worry about leaving their land vacant or in the hands of somebody else. In fact, it is explained by Robert Desjardins that this very problem contributed to the failure of Philip's crusading plans with Pope Calixtus III that had been planned for the year 1456. Philip sent an embassy to Charles VII asking him to safeguard his estates, but Charles refused unless Philip gave him rule over the towns on the Somme, a heavy and seemingly unfair price for Philip to pay. ${ }^{28}$ Tinctor's proposal for a "witch-crusade" in their own duchy would effectively eliminate Burgundy's reliance on its neighbours for aid in such matters.

The close proximity of witches in comparison to "Saracens" would certainly mean a significantly less expensive method of obtaining the same, if not more illustrious, crusading reputation. In fact, according to Tinctor, the sect of witches was far worse than the "sin of bad faith of the Saracens". ${ }^{29}$ He stated, "I dare to affirm that the contagious and pestilential venom of the witches is worse by far and more dangerous and full of the greatest madness." ${ }^{30}$ His reasoning was that although the Muslims refused to acknowledge the divine incarnation and holy Cross, and through the Qur'an, "pervert the holy Scriptures of the New and Old Testaments," they still rejected idol worship, they did not sacrifice to any creature but God and they adored the divine. ${ }^{31}$ In contrast, he accused the witches of idol worship, adoration of the Devil, satanic sacrifice, among countless other unpardonable acts sure to raise the alarm of any Christian. ${ }^{32}$ Essentially, Tinctor explained that the difference between "Saracens" and vaudois was consciousness of sin. Tinctor all but pardoned the "Saracens" for mere ignorance of proper Catholic doctrine, which was of minor concern when compared to the witches who were conscious of their heresy and obstinate in their error. ${ }^{33}$ The time Tinctor spent comparing witches to Muslims is important because even the mention of the word "Saracen" in this way would have drawn very direct crusading connotations for the knights of Burgundy, already laden with the word from chivalric literature and every day life at court. It is fascinating to find that Tinctor would go so far as to expose any redeeming qualities in Islam, the legendary foe of Christianity, but the fact that he did so substantially magnified the dangers of the new sect of vaudois. The fact that Tinctor decided to diminish the threat of the "Saracens" to bolster the dangers of his own sect suggests that a crusade against the vaudois would have proven to be even more beneficial to Christendom, and evermore meritorious for crusaders, than a traditional eastern expedition.

\footnotetext{
${ }^{26}$ Tinctor, Invectives, Fol. $18 \mathrm{v}$.

${ }^{27}$ Desjardins, "Writing and Imagining the Crusade," 58.

${ }^{28}$ Desjardins, "Writing and Imagining the Crusade," 58.

${ }^{29}$ Tinctor, Invectives, $7 \mathrm{v}$.

${ }^{30}$ Tinctor, Invectives, $25 \mathrm{r}$.

${ }^{31}$ Tinctor, Invectives, $25 \mathrm{r}-25 \mathrm{v}$.

32 Tinctor, Invectives, $25 \mathrm{v}$.

${ }^{33}$ Tinctor, Invectives, fol. 22r.
} 
In another sense, Tinctor implicitly used the recent threats of Islam to his advantage in the way he described the vaudois:

...who, at the instigation of the most cruel and bloody enemy of humankind, has in these last days risen up and has now horribly infected a great part of Christendom and has grown so much that it has even penetrated the farthest marches of France which alone used to be free of such monstrous things and shone above all other countries in the purity of holy faith. ${ }^{34}$

This passage runs parallel to the sort of issues that French Christendom was facing at the time. As previously addressed, the lasting shock of the fall of Constantinople remained fresh in the minds of Western Europeans. Speaking of the vaudois in terms of a conquering force, penetrating Christendom and infecting it with evil should immediately raise the alarm of a nation aspiring to crusade, and especially one that was still feeling a lingering anxiety from a very recent and similar threat.

The benefits that came from crusade are also important to consider here. As is written in the Les Trois fils de roi, "If you undertake a holy journey against the Turks in Sicily, your fame, after your death, will surpass Alexander's and Hector's renown." ${ }^{35}$ This statement embodies the reputational value of crusades. As previously mentioned, the crusade translated to glory, honour and hereditary reputation, and reputation was paramount to any knight. All of these things were promised by Tinctor to those who took to heart his exhortations against the sect of witches. Of this kind of crusade, he stated that, "in doing so, you [the princes] will earn sovereign celestial glory, and the praise of the world, which will last forever for you and your descendants." ${ }^{36}$ Tinctor called on the princes to, "gain for [their] name perpetual blessings from the mouths of the people." ${ }^{37}$ Here Tinctor promised the typical rewards of the crusade.

In fact, Tinctor continued to make a case that the mere persistence of this sect could be more harmful, in a way particular to the princes, than the persistence of any other sect:

And therefore, most noble, most excellent and most brilliant princes of France, may it please you to think of these matters, may it please you to hand down to your descendants this high honour which your most noble ancestors have left to you. For God's sake, take courage and be diligent and eager to extinguish this most poisonous and detestable sect of witches, who are trying to remove from you or sully the most bright and brilliant light of your hereditary glory of purity in the holy faith. $^{38}$

\footnotetext{
${ }^{34}$ Tinctor, Invectives, Fol. $15 \mathrm{v}$.

${ }^{35}$ Michelle Szkilnik, "Three new worthies: Les Trois fils de roi," Electronic Antiquity 14 (2010): 109, accessed December 8, 2013, http://scholar.lib.vt.edu/ejournals/ElAnt/V14N1/pdf/szkilnik.pdf.

${ }^{36}$ Tinctor, Invectives, Fol. 45r.

${ }^{37}$ Tinctor, Invectives, Fol. 45r.

${ }^{38}$ Tinctor, Invectives, Fol. $47 \mathrm{v}-48 \mathrm{r}$.
} 
This is an extremely important passage, for Tinctor warned the princes that this sect posed an immediate threat to their reputation, this same hereditary reputation. Attainment of this kind of reputation was the very reason that these nobles dreamt of crusade. Tinctor applied this section to the crusading rewards of ancestral glory. He implied that any lack of action would actually harm the reputation of their heirs, and also shame their ancestors, like John the Fearless, and rob them of rewards gained in previous expeditions. By taking these steps in his treatise, Tinctor created a very personal conflict between witches and crusading nobility. He made war necessary for these men. Here, he justified this war by providing grounds for self-defence, or defence of their reputation.

The more explicit usage of crusading imagery can be found within Tinctor's exhortations to the prelates, princes and other elite. Even outside the context of Burgundy and consideration of his audience, his careful choice of words conjures deliberate images of warfare. His exhortation to the prelates called for a spiritual crusade, as he stated that:

You [the prelates] do not need now to take the field and fight against corporeal enemies of flesh and blood, but you must wage war on the governors of this darkness and of the present age, which are the demons. You must do battle with the spiritual evils that fell from the heavens long ago. ${ }^{39}$

Tinctor was indisputably blatant in his warlike imagery here. It became the duty of the prelates to preach against the vaudois, to wage an incorporeal war against the spiritual enemies of Christ. In fact, Tinctor expressed that it would be a sin in itself for these men to remain silent. ${ }^{40} \mathrm{He}$ continued as he called on the prelates, for example, to "...sound the trumpets of holy doctrine and the silvered clarion of evangelical preaching," providing direct connotations to a holy call to arms. ${ }^{41} \mathrm{He}$ implored the prelates to "...go up chivalrously on the wall to protect the fortress of the true Catholic faith," and to "...be the bulwark and the shield of the house of Israel, that is, of holy Christendom." ${ }^{42}$ Even more explicit, he entreated these men to make use of the "holy armour of God" and "equip [themselves] with his weapons": "the holy helmet of eternal salvation and the spiritual sword of the word of God." ${ }^{43}$ These exhortations in themselves bring together motifs of war, immediately and deeply intermingled with Christian terminology; they are a wedding of war and religion. Tinctor went on to rally his Christian soldiers:

You will put on the holy armour of God and you will equip yourselves with his weapons, so that you can resist these sharp needles and harsh attacks of the devil," and he wrote also to "...take the superb and shining armour which the Holy Spirit has made for you his champions... ${ }^{44}$

\footnotetext{
${ }^{39}$ Tinctor, Invectives, Fol. 41r-41v.

${ }^{40}$ Tinctor, Invectives, Fol. 40v.

${ }^{41}$ Tinctor, Invectives, Fol. 39r.

${ }^{42}$ Tinctor, Invectives, Fol. 39r.

${ }^{43}$ Tinctor, Invectives, Fol. 41r-42r.

${ }^{44}$ Tinctor, Invectives, Fol. 41r-41v.
} 
Tinctor explicitly referred to those who pursued the extermination of witches as the champions of God, virtually labelling them crusaders in a holy war and, of course, special individuals in the eyes of God.

Where Tinctor calls upon these prelates to face this new foe on a spiritual level, he made an admonition to the secular arm to put these evil enemies of Christianity to the earthly sword. Tinctor reminded the princes that it was their divine calling to judge and condemn evil, and to defend the laws of God, for they "do not carry the sword without reason." ${ }^{45}$ He implored the princes to "wage this war chivalrously for the defence of the most holy faith of God," again reminding the princes of their role as defenders of the faith. ${ }^{46}$ Indeed, his use of the words "war" and "chivalry" and "holy faith" in the same phrase cannot have been a mistake. In this phrase alone, Tinctor exposed his intention to conjure crusading emotions in his readers and have his readers relate these emotions to the task in which he wished them to partake. And Tinctor, once again, promised the rewards of crusade:

...you [the princes] will be numbered among the glorious host of the real protectors, champions, guards and defenders of the most worthy Christian law, but you should abolish and erase all traces of the depraved vanities and false inventions of this accursed sect. $^{47}$

Tinctor applied and modified his demonological Invectives to appeal to the very particular culture of the Burgundian court. This text is unique in its rousing crusading tone, for later treatises like the Malleus were to be written in a different tone and style altogether, and even vary in their arguments. Tinctor made this imaginary sect of vaudois seem so absolutely evil that their persecution would be the greatest and most Christian act that any ruler or prince could ever undertake, indeed more Christian than doing battle against the "Saracens". He provided a wonderful opportunity for the knights of Burgundy, starving for crusade, to finally embark upon a chivalrous adventure, and to gain renown to rival that of Alexander the Great or Hector, without leaving their own duchy and at little expense. Tinctor's use of crusading imagery was a strategic measure in order to convince the nobility of ideas about malefic witchcraft that had traditionally been dismissed as harmless superstition or impossibility by earlier medieval canon, such as canon Episcopi. ${ }^{48}$ Despite all this, Tinctor, it seems, failed to capture the emotions of men like Popaincourt in time to affect the outcome of the Arras appeals, which ruled in favour of Colard de Beaufort in 1469. The duchy of Burgundy itself vanished in 1477 when Philip's son, Charles the Bold, left his title without a male heir. His daughter Mary of Burgundy was wed to Emperor Maximilian I of the Habsburg Dynasty, who inherited its riches, prestige and even the Order of the Golden Fleece, assimilating these elements into the ever-growing Holy Roman Empire. Ultimately, the promising political unit of Burgundy was divided out of existence. Considering this, Tinctor's particular persuasive strategies of appealing to the idea of crusade, Burgundy's unique court culture and its dreams of romantic chivalry, may have missed its opportunity to reach as many willing ears as he may have initially wished. However, the "elaborated theory of witchcraft" was, nonetheless, perpetuated and disseminated by learned

\footnotetext{
${ }^{45}$ Tinctor, Invectives, Fol. 42v.

${ }^{46}$ Tinctor, Invectives, Fol. $48 \mathrm{v}$.

${ }^{47}$ Tinctor, Invectives, Fol. 48v-49r.

${ }^{48}$ Canon Episcopi rejected the possibility of the night-flight.
} 
demonologists. Through similar means, it seeped into the collective mind of Europe and contributed to the great and famous witch-crazes of the early modern period, lasting well into the eighteenth century. 


\section{Bibliography:}

\section{Primary Sources:}

"Appeal to the Parlement of Paris." Unpublished; translated by Andrew Gow, Robert Desjardins and François Pageau.

Tinctor, Johannes. Inectives contre la secte de vauderie. Unpublished; translated by Andrew Gow, Robert Desjardins and François Pageau.

\section{Secondary Sources:}

Desjardins, Robert. "Writing and Imagining the Crusade in Fifteenth-Century Burgundy: The Case of the Expedition Narrative in Jean de Wavrin's Anciennes Chroniques d'Angleterre." PhD Diss., University of Alberta, 2010.

Hankins, James. "Renaissance Crusaders: Humanist Crusade in the Age of Mehmet II." Dumbarton Oaks Papers 49 (1995): 111-207. Accessed December 8, 2013. http://www.jstor.org/stable/1291712.

Moodey, Elizabeth J. Illuminated Crusader Histories for Philip the Good of Burgundy. Belgium: Brepols Publishers, 2012.

Orgelfinger, Gail. "The Vows of the Pheasant and Late Chivalric Ritual." In The Study of Chivalry: Resources and Approaches, edited by Howard Chickering, and Thomas H. Seiler, 611-643. Michigan: Medieval Institute Publications, 1988.

Paviot, Jacques. "Burgundy and the Crusade." In Crusading in the Fifteenth Century: Message and Impact, edited by Norman Housley, 70-80.UK: Palgrave Macmillan Ltd., 2004.

Szkilnik, Michelle. "Three new worthies: Les Trois fils de roi." Electronic Antiquity 14 (2010): 109-126. Accessed December 8, 2013. http://scholar.lib.vt.edu/ejournals/ElAnt/V14N1/pdf/szkilnik.pdf.

Williams, Gerhild. "How to Make Friends: Burgundian Politics in Two Early Modern Prose Texts (Hug Schapler and Girart de Roussillon)." The Sixteenth Century Journal 20 (1989): 277-292. Accessed December 8, 2013. http://www.jstor.org/stable/2540663.

Wrisley, David. "The Loss of Constantinople and Imagining Crusade at the Fifteenth-Century Court of Burgundy." al-Abhath 55 (2007-08). 85-112. http://www.academia.edu/2049348/_The_Loss_of_Constantinople_and_Imagining_Crusade at the_Fifteenth-

Century_Court_of_Burgundy_alAbhath_55_2007-08_81-115 